\title{
Effect of Organic and Inorganic Sources of Nutrients on Yield Attributes and Yield of Groundnut (Arachis hypogaea L.)
}

\author{
P. Murugan*, P. Kumaravel and N. Akila \\ Krishi Vigyan Kendra, Tamil Nadu Veterinary and Animal Sciences University \\ Namakkal - 637002, Tamil Nadu, India \\ *Corresponding author
}

\section{Keywords \\ Composted poultry manure, Fish pod silt, Groundnut, vermicompost, Yield}

\section{Article Info}

Accepted:

23 April 2020 Available Online: 10 May 2020

\section{A B S T R A C T}

Field experiments were carried out to study the effect of different sources of organic manures and inorganic fertilizers on yield attributes and yield of groundnut at Krishi Vigyan Kendra, Tamil Nadu Veterinary and Animal Sciences University, Kattupakkam during Rabi 2014 and 2015. The experiments were laid out in split-plot design consisting of twelve treatments with 3 replications. The main plot consisted of Farm yard manure @ $12.5 \mathrm{t} \mathrm{ha}^{-1}$ (M1), Vermicompost @ $5.0 \mathrm{t} \mathrm{ha}^{-1}$ (M2), Fish pond silt @ $5.0 \mathrm{t} \mathrm{ha}^{-1}$ (M3) and Composted poultry manure @ $5.0 \mathrm{t} \mathrm{ha}^{-1}$ (M4) and sub plot consisted of 100 per cent recommended dose of fertilizers NPK (S1), 75 per cent recommended dose of NPK (S2) and 50 per cent of recommended dose of NPK (S3). Data on yield parameters viz., Number of pods plant ${ }^{-1}$, Number of kernels pod ${ }^{-1}, 100$ kernel weight ( $\mathrm{g}$ ), pod yield and haulm yield of groundnut $\left(\mathrm{kg} \mathrm{ha}^{-1}\right)$ were collected for different treatments. Results revealed that application of vermicompost @ $5.0 \mathrm{t} \mathrm{ha}^{-1}\left(\mathrm{M}_{2}\right)$ recorded significantly higher number of pods plant ${ }^{-1}$ (24 and 25 nos.), higher groundnut pod yield $\left(2488\right.$ and $\left.2549 \mathrm{~kg} \mathrm{ha}^{-1}\right)$ and higher haulm yield (4170 and $4279 \mathrm{~kg} \mathrm{ha}^{-1}$ ) as compared to other organic manure treatment in both the season. Similar trend was observed in the case of number of kernel $\operatorname{pod}^{-1}$ also, whereas, the 100 kernel weight was not significant due to the application of different organic manure. In addition, application of recommended dose of 100 per cent NPK $\left(S_{1}\right)$ significantly recorded higher number of pods plant ${ }^{-1}$ (22.9 and 24 nos.), higher groundnut pod yield (2436 and $2490 \mathrm{~kg} \mathrm{ha}^{-1}$ ) and higher haulm yield (4092 and $4190 \mathrm{~kg}$ $\mathrm{ha}^{-1}$ ) over 75 and 50 per cent of NPK levels in both the years. However, the interaction between organic manures and fertilizer levels were not significant on number of kernel $\operatorname{pod}^{-1}, 100$ kernel weight, pod yield and haulm yield of groundnut but highly significant on number of pods plant ${ }^{-1}$. The study showed that groundnut crop responded well in terms of yield attributes, pod yield and haulm yield by the application of vermicompost @ $5.0 \mathrm{t} \mathrm{ha}^{-1}$ and 75 per cent recommended dose of NPK fertilizers.

\section{Introduction}

Groundnut (Arachis hypogaea L.) is a unique and important oilseed crop of Tamil Nadu. In
Tamil Nadu, groundnut is cultivated in 3.39 lakh ha with a production of 7.85 lakh tonnes and productivity of $2751 \mathrm{~kg} \mathrm{ha}^{-1}$ (2012-13). The groundnut kernel is used mainly for 
edible oil and contains nearly half of the essential vitamins and one-third of the essential minerals. Hence, groundnut played an important role in nutritional security to the resource poor farmers. In addition, the haulms provided excellent fodder for livestock, cake obtained after oil extraction was used in animal feed and overall the crop acted as good source of biological nitrogen fixation (Nautiyal et al., 2011). In recent years, crop cultivation requires the use of chemical fertilizer, but it is expensive for people who have not capacity to buy fertilizer. Therefore, the current trend is to explore the possibilities of supplementing organic manures like farm yard manure, vermicompost, poultry manure etc. Indigenously available organic sources of nutrients have enhanced the efficiency and reduced the requirements of chemical fertilizers (Bhat et al., 2007). Hence, it is necessary to integrate different sources of nutrients to meet the crop requirement. Such integrated approach with special emphasis on combined application of inorganic fertilizers with organic manures would sound well in oilseed crops like groundnut grown under aberrated climatic conditions. Therefore, an experiment was conducted to study the effect of integrated use of organic and inorganic sources of nutrients on yield of groundnut in Kancheepuram district of Tamil Nadu.

\section{Materials and Methods}

Field experiments were carried out to study the effect of different sources of organic and inorganic nutrients on yield attributed and yield of groundnut at Krishi Vigyan Kendra, Tamil Nadu Veterinary and Animal Sciences University, Kattupakkam located at North Eastern zone of Tamil Nadu at lies between $11^{\circ} 00^{\prime}$ to $12^{\circ} 00^{\prime}$ North latitudes and $77^{\circ} 28^{\prime}$ to $78^{\circ} 50^{\prime}$ East longitudes during Rabi 2014 and 2015. The soil of the experimental site was moderately well drained, sandy clay loam in texture and chemical analysis showed low in available nitrogen (199.5 $\left.\mathrm{kg} \mathrm{ha}^{-1}\right)$, medium in available phosphorus (19.8 $\mathrm{kg} \mathrm{ha}^{-1}$ ) and high in available potassium (461.3 kg ha $\mathrm{kg}^{-1}$, 0.55 per cent of organic carbon and $7.8 \mathrm{pH}$ of the soil. The experiments were laid out in split-plot design consisting of twelve treatments (four main and three sub plots) with 3 replications. The main plot consisted of Farm yard manure @ 12.5 t ha ${ }^{-1}(\mathrm{M} 1)$, Vermicompost@5.0 t ha ${ }^{-1}$ (M2), Fish pond silt @ $5.0 \mathrm{t} \mathrm{ha}^{-1}$ (M3) and Composted poultry manure@5.0 t ha ${ }^{-1}$ (M4) and sub plot consisted of 100 per cent (25:50:75 kg NPK $\mathrm{ha}^{-1}$ ) recommended dose of fertilizers (S1), 75 per cent recommended dose of fertilizers (S2) and 50 per cent of recommended dose of fertilizers (S3).

The groundnut variety $T M V-13$ was used for treatment. Beds and channel were formed, layout was taken and organic manures were applied to each plot in accordance with the treatments assigned, incorporated manually and levelled. The seeds were sown in a plot size of $6.0 \mathrm{~m} \times 5.0 \mathrm{~m}$ spaced with $30 \times 10 \mathrm{~cm}$ for each treatment during Rabi 2014 and 2015. Full dose of phosphorus and potassium along with half dose of nitrogen in all the treatments was applied as basal. Remaining dose of nitrogen was applied at 30 days after sowing at the time of weeding as per the treatments. All other recommended cultural practices and prophylactic plant protection measures were followed to raise healthy crop. Observations were recorded in 10 randomly taken and tagged plants from each replication on Number of pods plant ${ }^{-1}$, Number of kernels $\operatorname{pod}^{-1}, 100$ kernel weight $(\mathrm{g})$, pod yield and haulm yield of groundnut $\left.(\mathrm{kg} \mathrm{ha})^{-1}\right)$ of different treatments. The harvested pods yield from each net plot cleaned separately as per the moisture content and expressed in $\mathrm{kg} \mathrm{ha}^{-1}$. The haulm yield of groundnut was recorded from the net plot area after enough sun drying and expressed in $\mathrm{kg} \mathrm{ha}^{-1}$. The data on various parameters were statistically analyzed in split 
plot design as suggested by Gomez and Gomez (2010). Wherever the treatment difference was significant, critical differences were worked out at five per cent probability level.

\section{Results and Discussion}

\section{Yield attributes of groundnut}

The number of pods plant ${ }^{-1}$ and number of kernel pod $^{-1}$ were positively influenced by the application of organic manures and different levels of NPK fertilizer, whereas 100 kernel weight of groundnut was not significantly influenced by the application of organic manures and different levels of NPK fertilizer during Rabi 2014 and 2015 (Table 1 and 2).

Among different organic manure application, vermicompost application @ $5.0 \mathrm{t} \mathrm{ha}^{-1}\left(\mathrm{M}_{2}\right)$ significantly recorded higher number of pods plant ${ }^{-1}$ (24 and 25 nos.) in both the years. The composted poultry manure application@ $5.0 \mathrm{t} \mathrm{ha}^{-1}\left(\mathrm{M}_{4}\right)$ was the next best treatment followed by the application of FYM @ $12.5 \mathrm{t} \mathrm{ha}^{-1}\left(\mathrm{M}_{1}\right)$ during both the years. Similar trend was observed in the case of number of kernel $\operatorname{pod}^{-1}$ also, whereas, the 100 kernel weight was not significant due to the application of different organic manure. With regard to different NPK fertilizer levels tried, higher number of pods plant $^{-1}$ (22.9 and 24 nos.) was observed with the application of 100 per cent recommended dose of NPK fertilizers $\left(S_{1}\right)$. It was followed by the application of 75 per cent recommended dose of NPK fertilizers $\left(S_{2}\right)$. These two were comparable with each other. Application of 50 per cent recommended dose of NPK fertilizers $\left(\mathrm{S}_{3}\right)$ registered lowest number of pods plant ${ }^{-1}$. Similar trend was observed for number of kernel $\operatorname{pod}^{-1}$ also. Different levels of recommended dose of NPK fertilizers did not show any significant improvement on the 100 kernel weight during both the years.

Interaction effect between organic manures and NPK fertilizers levels was highly significant on number of pods plant $^{-1}$ in both the years. Combined application of vermicompost@5.0 t ha ${ }^{-1}$ along with 75 per cent of recommended dose of NPK $\left(\mathrm{M}_{2} \mathrm{~S}_{2}\right)$ registered higher number of pods plant ${ }^{-1}(26.3$ and 27.4 nos) in both the years. It was on par with application of vermicompost along with 100 per cent of recommended dose of NPK fertilizers $\left(M_{2} S_{1}\right)$ in both the years. The interaction effect on number of kernel pod $^{-1}$ and 100 kernel weight of groundnut was not at all significant in both the years.

\section{Pod yield of groundnut}

Groundnut pod yield was significantly influenced due to the application of organic manures and different levels of NPK fertilizers during both the years. Among organic manures application, vermicompost application @ $5.0 \mathrm{t} \mathrm{ha}{ }^{-1}\left(\mathrm{M}_{2}\right)$ recorded significantly higher groundnut pod yield of 2488 and $2549 \mathrm{~kg} \mathrm{ha}^{-1}$ during Rabi 2014 and 2015 , respectively. It was followed by the application of composted poultry manure treatment @ $5.0 \mathrm{t} \mathrm{ha}^{-1}\left(\mathrm{M}_{4}\right)$, which recorded on yield of 2379 and $2417 \mathrm{~kg} \mathrm{ha}^{-1}$. The lowest groundnut pod yield of 2344 and $2391 \mathrm{~kg} \mathrm{ha}^{-1}$ was observed with fish pond silt @ $5.0 \mathrm{t} \mathrm{ha}^{-1}$ $\left(\mathrm{M}_{3}\right)$ during Rabi 2014 and 2015, respectively (Table 3 and 4).

Regarding fertilizer levels, application of recommended dose of 100 per cent NPK fertilizers $\left(S_{1}\right)$ significantly recorded higher groundnut pod yield of 2436 and $2490 \mathrm{~kg} \mathrm{ha}^{-1}$ during Rabi 2014 and 2015, respectively. It was on par with the application of 75 per cent of NPK fertilizers $\left(S_{2}\right)$, which recorded on yield of 2421 and $2463 \mathrm{~kg} \mathrm{ha}^{-1}$ during Rabi 2014 and 2015, respectively. 
Table.1 Effect of treatments on yield attributes of groundnut during Rabi 2014

\begin{tabular}{|c|c|c|c|c|c|c|c|c|c|c|c|c|}
\hline \multirow[t]{2}{*}{ Treatments } & \multicolumn{4}{|c|}{ Number of pods plant ${ }^{-1}$} & \multicolumn{4}{|c|}{ Number of kernel pod $^{-1}$} & \multicolumn{4}{|c|}{100 kernel weight (g) } \\
\hline & $\mathbf{S}_{1}$ & $\mathbf{S}_{2}$ & $\mathbf{S}_{\mathbf{3}}$ & Mean & $\mathbf{S}_{1}$ & $\mathbf{S}_{2}$ & $\mathbf{S}_{\mathbf{3}}$ & Mean & $\mathbf{S}_{1}$ & $\mathbf{S}_{2}$ & $\mathbf{S}_{3}$ & Mean \\
\hline $\mathbf{M}_{1}$ & 22.0 & 21.2 & 19.4 & 20.8 & 1.61 & 1.60 & 1.50 & 1.57 & 44.1 & 44.0 & 44.0 & 44.0 \\
\hline $\mathbf{M}_{2}$ & 23.6 & 26.3 & 22.4 & 24.0 & 1.64 & 1.69 & 1.62 & 1.64 & 44.2 & 44.6 & 44.2 & 44.3 \\
\hline $\mathbf{M}_{3}$ & 22.2 & 20.6 & 19.2 & 20.6 & 1.54 & 1.52 & 1.50 & 1.52 & 43.9 & 43.8 & 43.7 & 43.8 \\
\hline $\mathbf{M}_{4}$ & 24.2 & 23.1 & 21.0 & 22.7 & 1.60 & 1.60 & 1.58 & 1.59 & 44.0 & 43.8 & 43.8 & 43.8 \\
\hline \multirow[t]{3}{*}{ Mean } & 22.9 & 22.8 & 20.5 & & 1.59 & 1.60 & 1.55 & & 44.0 & 44.0 & 43.9 & \\
\hline & \multicolumn{4}{|c|}{ Number of pods plant ${ }^{-1}$} & \multicolumn{4}{|c|}{ Number of kernel pod ${ }^{-1}$} & \multicolumn{4}{|c|}{100 kernel weight (g) } \\
\hline & $\mathbf{M}$ & $\mathbf{S}$ & $\mathbf{M}$ at $\mathbf{S}$ & $\mathbf{S}$ at $\mathbf{M}$ & $\mathbf{M}$ & $\mathbf{S}$ & $\mathbf{M}$ at $\mathbf{S}$ & $\mathbf{S}$ at $\mathbf{M}$ & $\mathbf{M}$ & $\mathbf{S}$ & $\mathbf{M}$ at $\mathbf{S}$ & $\mathrm{S}$ at $\mathrm{M}$ \\
\hline SEd & 0.1 & 0.2 & 0.3 & 0.4 & 0.01 & 0.01 & 0.03 & 0.03 & 0.5 & 0.3 & 0.8 & 0.7 \\
\hline $\mathrm{CD}(\mathrm{P}=\mathbf{0 . 0 5})$ & 0.2 & 0.4 & 0.7 & 0.8 & 0.03 & 0.03 & NS & NS & NS & NS & NS & NS \\
\hline \multicolumn{13}{|c|}{$\begin{array}{l}\mathrm{M}_{1} \text { - FYM @12.5 t ha } \\
\mathrm{M}_{2} \text { - Vermicompost @ } 5.0 \mathrm{t} \mathrm{ha}^{-1} \\
\mathrm{M}_{3} \text { - Fish pond silt @ } 5.0 \mathrm{t} \mathrm{ha}^{-1} \\
\mathrm{M}_{4} \text { - Composted poultry manure @ } 5.0 \mathrm{t} \mathrm{ha}^{-1}\end{array}$} \\
\hline
\end{tabular}


Table.2 Effect of treatments on yield attributes of groundnut nut during Rabi 2015

\begin{tabular}{|c|c|c|c|c|c|c|c|c|c|c|c|c|}
\hline \multirow[t]{2}{*}{ Treatments } & \multicolumn{4}{|c|}{ Number of pods plant ${ }^{-1}$} & \multicolumn{4}{|c|}{ Number of kernel pod ${ }^{-1}$} & \multicolumn{4}{|c|}{100 kernel weight (g) } \\
\hline & $\mathbf{S}_{1}$ & $\mathbf{S}_{2}$ & $\mathbf{S}_{3}$ & Mean & $\mathbf{S}_{1}$ & $\mathbf{S}_{2}$ & $\mathbf{S}_{\mathbf{3}}$ & Mean & $\mathbf{S}_{1}$ & $\mathbf{S}_{\mathbf{2}}$ & $\mathbf{S}_{\mathbf{3}}$ & Mean \\
\hline $\mathbf{M}_{1}$ & 23.2 & 22.5 & 20.2 & 21.9 & 1.62 & 1.56 & 1.50 & 1.56 & 44.2 & 44.1 & 44.0 & 44.1 \\
\hline $\mathbf{M}_{2}$ & 24.2 & 27.4 & 23.5 & 25.0 & 1.61 & 1.68 & 1.60 & 1.63 & 44.2 & 44.6 & 44.2 & 44.3 \\
\hline $\mathbf{M}_{3}$ & 23.1 & 21.7 & 20.1 & 21.6 & 1.55 & 1.50 & 1.50 & 1.51 & 44.0 & 43.9 & 43.9 & 43.9 \\
\hline $\mathbf{M}_{4}$ & 25.6 & 24.8 & 22.2 & 24.2 & 1.61 & 1.60 & 1.58 & 1.59 & 44.2 & 44.0 & 44.0 & 44.0 \\
\hline \multirow[t]{3}{*}{ Mean } & 24.0 & 24.1 & 21.4 & & 1.59 & 1.58 & 1.54 & & 44.1 & 44.1 & 44.0 & \\
\hline & \multicolumn{4}{|c|}{ Number of pods plant ${ }^{-1}$} & \multicolumn{4}{|c|}{ Number of kernel pod ${ }^{-1}$} & \multicolumn{4}{|c|}{100 kernel weight (g) } \\
\hline & $\mathbf{M}$ & $\mathbf{S}$ & $M$ at $\mathbf{S}$ & $\mathbf{S}$ at $\mathbf{M}$ & $\mathbf{M}$ & $\mathbf{S}$ & $M$ at $S$ & $\mathbf{S}$ at $\mathbf{M}$ & $\mathbf{M}$ & $\mathbf{S}$ & $M$ at $S$ & $\mathrm{~S}$ at $\mathrm{M}$ \\
\hline SEd & 0.3 & 0.2 & 0.4 & 0.4 & 0.01 & 0.02 & 0.03 & 0.04 & 0.7 & 0.3 & 0.9 & 0.7 \\
\hline $\mathrm{CD}(\mathrm{P}=0.05)$ & 0.8 & 0.4 & 1.1 & 0.9 & 0.04 & 0.04 & NS & NS & NS & NS & NS & NS \\
\hline
\end{tabular}

Main Plot

$\mathrm{M}_{1}$ - FYM @12.5 tha ${ }^{-1}$

$\mathrm{M}_{2}$ - Vermicompost @ $5.0 \mathrm{tha}^{-1}$

$\mathrm{M}_{3}$ - Fish pond silt @ $5.0 \mathrm{t} \mathrm{ha}^{-1}$

$\mathrm{M}_{4}$ - Composted poultry manure @ $5.0 \mathrm{t} \mathrm{ha}^{-1}$
$\mathrm{S}_{1}-100$ per cent recommended NPK

$\mathrm{S}_{2}-75$ per cent recommended NPK

$\mathrm{S}_{3}-50$ per cent recommended NPK 
Table.3 Effect of treatments on pod and haulm yield of groundnut during Rabi 2014

\begin{tabular}{|c|c|c|c|c|c|c|c|c|}
\hline \multirow[t]{2}{*}{ Treatments } & \multicolumn{4}{|c|}{ Pod yield $\left(\mathrm{kg} \mathrm{ha}^{-1}\right)$} & \multicolumn{4}{|c|}{ Haulm yield (kg ha $\left.{ }^{-1}\right)$} \\
\hline & $\mathbf{S}_{1}$ & $\mathbf{S}_{\mathbf{2}}$ & $\mathbf{S}_{\mathbf{3}}$ & Mean & $\mathbf{S}_{1}$ & $\mathbf{S}_{\mathbf{2}}$ & $\mathbf{S}_{\mathbf{3}}$ & Mean \\
\hline $\mathbf{M}_{1}$ & 2411 & 2368 & 2306 & 2362 & 4096 & 3915 & 3825 & 3945 \\
\hline $\mathbf{M}_{2}$ & 2476 & 2595 & 2392 & 2488 & 4152 & 4350 & 4007 & 4170 \\
\hline $\mathbf{M}_{3}$ & 2405 & 2340 & 2286 & 2344 & 3984 & 3923 & 3813 & 3907 \\
\hline $\mathbf{M}_{4}$ & 2451 & 2381 & 2306 & 2379 & 4136 & 3946 & 3905 & 3996 \\
\hline \multirow[t]{3}{*}{ Mean } & 2436 & 2421 & 2323 & & 4092 & 4033 & 3887 & \\
\hline & \multicolumn{4}{|c|}{ Pod yield (kg ha $\left.{ }^{-1}\right)$} & \multicolumn{4}{|c|}{ Haulm yield $\left(\mathrm{kg} \mathrm{ha}^{-1}\right)$} \\
\hline & $\mathbf{M}$ & $\mathbf{S}$ & $\mathbf{M}$ at $\mathbf{S}$ & $S$ at $M$ & $\mathbf{M}$ & $\mathbf{S}$ & $M$ at $S$ & $\mathrm{~S}$ at $\mathrm{M}$ \\
\hline SEd & 40 & 22 & 54 & 43 & 85 & 44 & 112 & 89 \\
\hline $\mathrm{CD}(\mathrm{P}=\mathbf{0 . 0 5})$ & 99 & 46 & NS & NS & NS & 94 & NS & NS \\
\hline
\end{tabular}

Table.4 Effect of treatments on pod and haulm yield of groundnut during Rabi 2015

\begin{tabular}{|c|c|c|c|c|c|c|c|c|}
\hline \multirow[t]{2}{*}{ Treatments } & \multicolumn{4}{|c|}{ Pod yield (kg ha $\left.{ }^{-1}\right)$} & \multicolumn{4}{|c|}{ Haulm yield $\left(\mathrm{kg} \mathrm{ha}^{-1}\right)$} \\
\hline & $\mathbf{S}_{1}$ & $\mathbf{S}_{2}$ & $\mathbf{S}_{\mathbf{3}}$ & Mean & $\mathbf{S}_{1}$ & $\mathbf{S}_{\mathbf{2}}$ & $\mathbf{S}_{\mathbf{3}}$ & Mean \\
\hline $\mathbf{M}_{1}$ & 2460 & 2405 & 2361 & 2409 & 4157 & 4126 & 3910 & 4064 \\
\hline $\mathbf{M}_{2}$ & 2565 & 2644 & 2439 & 2549 & 4251 & 4468 & 4117 & 4279 \\
\hline $\mathbf{M}_{3}$ & 2451 & 2385 & 2337 & 2391 & 4098 & 4012 & 3922 & 4011 \\
\hline $\mathbf{M}_{4}$ & 2486 & 2419 & 2345 & 2417 & 4253 & 4026 & 3998 & 4092 \\
\hline \multirow[t]{3}{*}{ Mean } & 2490 & 2463 & 2370 & & 4190 & 4158 & 3987 & \\
\hline & \multicolumn{4}{|c|}{ Pod yield (kg ha ${ }^{-1}$ ) } & \multicolumn{4}{|c|}{ Haulm yield $\left(\mathrm{kg} \mathrm{ha}^{-1}\right)$} \\
\hline & $\mathbf{M}$ & $\mathbf{S}$ & $M$ at $S$ & $\mathbf{S}$ at $\mathbf{M}$ & $\mathbf{M}$ & $\mathbf{S}$ & $\mathbf{M}$ at $\mathrm{S}$ & $\mathbf{S}$ at $\mathrm{M}$ \\
\hline SEd & 21 & 22 & 42 & 44 & 33 & 51 & 90 & 102 \\
\hline $\mathrm{CD}(\mathrm{P}=\mathbf{0 . 0 5})$ & 52 & 47 & NS & NS & 81 & 108 & NS & NS \\
\hline
\end{tabular}


Application of $50 \%$ recommended dose of NPK fertilizers recorded the lowest groundnut pod yield of 2323 and $2370 \mathrm{~kg} \mathrm{ha}^{-1}$ in both the years. The interaction effect between organic manures and NPK fertilizer levels was nonsignificant on groundnut pod yield in both the years.

\section{Haulm yield of Groundnut}

Groundnut haulm yield was significantly influenced by the application of organic manures and different levels of NPK fertilizers in the both the years (Table 3 and 4). Application of vermicompost @ $5.0 \mathrm{t} \mathrm{ha}$ ${ }^{1}\left(\mathrm{M}_{2}\right)$ recorded significantly higher groundnut haulm yield of 4170 and $4279 \mathrm{~kg} \mathrm{ha}^{-1}$ in during Rabi 2014 and 2015, respectively. It was followed by the application of composted poultry manure @ 5.0 t ha $^{-1}$ (3996 and 4092 $\left.\mathrm{kg} \mathrm{ha}{ }^{-1}\right)$. The fish pond silt $\left(\mathrm{M}_{3}\right)$ recorded conspicuously the lowest groundnut haulm yield. Among the different fertilizer levels tried, application of 100 per cent recommended dose of NPK fertilizers $\left(S_{1}\right)$ recorded significantly higher groundnut haulm yield of 4092 and $4190 \mathrm{~kg} \mathrm{ha}^{-1}$ during Rabi 2014 and 2015, respectively. It was on par with the application of $75 \%$ recommended dose of NPK fertilizers $\left(\mathrm{S}_{2}\right)$ in both the years. The lowest groundnut haulm yield was observed with the application of 50 per cent recommended dose of NPK fertilizers $\left(S_{3}\right)$. Interaction effect between organic manures and fertilizer levels did not exhibit any significant variations on the haulm yield of groundnut in both the years.

Number of groundnut pods plant ${ }^{-1}$, pod yield and haulm yield was positively influenced by the application of organic manures and different levels of NPK fertilizer during both the years. Combined application of vermicompost and 75 per cent of recommended dose of fertilizers recorded significantly higher yield compared to lower level of NPK fertilizers. The yield improvement could be attributed to continuous availability of nutrients, growth promoting effect of vermicompost and ultimately leads more photosynthetic activities, cell division and cell elongation, enhanced carbohydrate as well as metabolic process and improvement of soil structure by increasing the soil water holding capacity, good aeration, which encourages better root growth and nutrient uptake. These results were corroborated with the findings of Ramasamy and Umapathi, (2010). The beneficial effect of vermicompost on yield and yield attributes might be attributed to its ability of sustain availability of nutrients throughout the growing season. The increased balanced $\mathrm{C}: \mathrm{N}$ ratio might have increased the synthesis of carbohydrates with ultimate improvement in yield and yield attributes. These findings corroborate with those of Mathivanan et al., (2012), Kondappa et al., (2009) and Yadav and Yadav (2010).

Poultry manure is excellent organic manure, since it contains high amount of nitrogen, phosphorus, potassium and other essential nutrients. Poultry manure improves the number of pods per plant, pod yield and haulm yield in groundnut as reported by Subrahmaniyan et al., (1999). Groundnut being a leguminous crop, capable of fixing atmospheric nitrogen and application of fertilizers including gypsum with organic manures enhanced the productivity of groundnut. Veeramani et al., (2012) observed similar findings.

In agricultural land soil fertility depletion is an important draw back due to continuous cultivation with inorganic nutrients. In order to increase the soil fertility, inorganic fertilizers are being widely utilized in cultivable lands. Even though they promote the growth of crops, their toxic effect is the negative impact by means of their over 
utilization of fertilizers. To overcome these factors, the combined application of organic manure especially vermicompost, poultry manures and farm yard manure along with NPK fertilizers is recommended. The study showed that the yield attributes, pod yield and haulm yield parameters of groundnut were enhanced by different sources of organic manures and levels of NPK fertilizers. Among the organic manure treatments, application of vermicompost performed better than the other sources through improved number of pods plant $^{-1}$, number of kernel pod ${ }^{-1}$, pod yield and haulm yield of groundnut crop. It could be concluded that the groundnut crop responded well in terms of yield attributes, pod yield and haulm yield by the application of vermicompost @ 5.0 t ha ${ }^{-1}$ and $75 \%$ recommended dose of NPK fertilizers.

\section{References}

Bhat, M.A., Singh, R and Kohli, A. 2007. Effect of integrated use of farm yard manure and fertilizer nitrogen with and without sulphur on yield and quality of Indian mustard. Journal of the Indian Society of Soil Science. 55 (2): 224226.

Gomez, K.A. and A.A. Gomez. 2010. Statistical procedures for Agricultural Research $\left(4^{\text {th }}\right.$ ed). Wiley India Pvt. Ltd., New Delhi, India.

Kondappa, D., B.M. Radder, P.L. Patil, N.S. Hebsur and S.C. Alagundagi. 2009. Effect of integrated nutrient management on growth, yield and economics of chilli in a vertisol. Karnataka Journal of Agricultural Sciences. 22: 438-440.

Mathivanan, S., A. Chidambaram, P. Sundaramoorthy and R. Bakiyaraj. 2012. Effect of vermicompost on growth and yield of groundnut. International Journal of Environmental Biology. 2 (1): 7 -11.

Nautiyal, P.C., Ravindra, V., Rathnakumar, A.L., Ajay, B.C., and Zala, P.V. 2011. Genetic variations in photosynthetic rate, pod yield and yield components in Spanish groundnut cultivars during three cropping seasons. Field Crops Research. 125: 83-91.

Ramasamy, P.K. and S. Umapathi. 2010. Efficacy of vermicompost on the head yield status of the sunflower plant (Helianthu annuus L.). Pollution Research. 29 (3):417-420.

Subrahmaniyan K. N., P. Arulmozhi and Kalaiselvan. 1999. Effect of irrigation layout, irrigation and fertilizer levels on the yield of rainfed groundnut. Crop Research. 18: 19-21.

Veeramani, P., K. Subrahmaniyan and V. Ganesaraja. 2012. Organic manure management on groundnut. Wudpecker Journal of Agricultural Research. 1(7): $238-243$.

Yadav, S.S. and N. Yadav. 2010. Effect of integrated nutrient management on yield of okra in zaid crop. Bhartiya Krishi Anusandhan Patrika, 25: 2-4.

\section{How to cite this article:}

Murugan, P., P. Kumaravel and Akila, N. 2020. Effect of Organic and Inorganic Sources of Nutrients on Yield Attributes and Yield of Groundnut (Arachis hypogaea L.). Int.J.Curr.Microbiol.App.Sci. 9(05): 2893-2900. doi: https://doi.org/10.20546/ijcmas.2020.905.332 